\title{
CDAN1 wt Allele
}

National Cancer Institute

\section{Source}

National Cancer Institute. CDAN1 wt Allele. NCI Thesaurus. Code C97931.

Human CDAN1 wild-type allele is located in the vicinity of $15 q 15.2$ and is approximately $14 \mathrm{~kb}$ in length. This allele, which encodes codanin-1 protein, may play a role in the maintenance of the nuclear envelope. Mutation of the gene is associated with congenital dyserythropoietic anemia type I. 